\title{
Studies on flower induction and improvement of fruit yield and its attributes in pomegranate (Punica granatum L.) CV. Bhagwa
}

\author{
S. Firoz Hussain , P. Syam Sundar Reddy, M.L.N. Reddy, B.N.S. Murthy, K.K. Upreti, R.H. Laxman and B. Srinivasulu \\ Dr. YSR Horticultural University, College of Horticulture, Anantharajupeta-516 105, Andhra Pradesh, India \\ *ICAR, Indian Institute of Horticultural Research, Hesaraghatta-560 089, Bengaluru, India
}

\section{Article Info}

Article history

Received 10 May 2021

Revised 27 June 2021

Accepted 28 June 2021

Published online 30 June 2021

\section{Keywords}

Bhagwa

Flower induction

Fruit yield

Hermaphrodite flowers

Pomegranate

Propagules

\begin{abstract}
The present study was conducted to elucidate the response of different propagules, i.e., tissue culture plants, grafted plants and air layer plants and chemicals, viz., methyl jasmonate $100 \mathrm{ppm}_{\text {plant }}{ }^{-1}$, MeJA

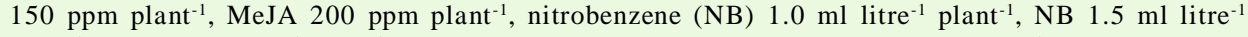

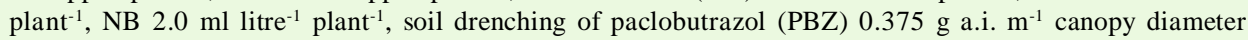
30 days after bahar treatment, soil drenching of PBZ $0.375 \mathrm{~g}$ a.i. $\mathrm{m}^{-1}$ canopy diameter 45 days after bahar treatment, soil drenching of PBZ $0.375 \mathrm{~g}$ a.i. $\mathrm{m}^{-1}$ canopy diameter 60 days after bahar treatment and control and their interaction effects on induction of flowering at the desired period with higher number of hermaphrodite flowers, percentage of fruit set, improved fruit yield and its attributes along with fruiting in pomegranate. Among the propagules, tissue culture plants produced highest number of hermaphrodite flowers, yield and its attributes during ambe bahar and hastha bahar. Among chemical treatments, soil drenching of paclobutrazol $0.375 \mathrm{~g}$ a.i. $\mathrm{m}^{-1}$ canopy diameter 60 days after bahar treatment resulted in highest number of hermaphrodite flowers, yield and its attributes. While in case of hastha bahar, application of nitrobenzene $2.0 \mathrm{ml}$ litre $^{-1}$ plant $^{-1}$ implicated in producing high number of hermaphrodite flowers plant $^{-1}$, yield and its attributes concomitant with fruiting parameters. Among interactions, tissue culture plants $\left(\mathrm{P}_{1}\right)$ produced significantly high number of hermaphrodite flowers, yield and its attributes along with fruiting parameters when soil drenched with paclobutrazol $0.375 \mathrm{~g}$ a.i. $\mathrm{m}^{-1}$ canopy diameter 60 days after bahar treatment during ambe bahar. During hastha bahar, application of nitrobenzene $2.0 \mathrm{ml} \mathrm{litre}^{-1}$ plant $^{-}$ ${ }^{1}$ to tissue culture plants and grafted plants resulted in production of higher number of hermaphrodite flowers, yield and its attributes along with fruiting parameters.
\end{abstract}

\section{Introduction}

Pomegranate (Punica granatum L.) of the family Punicaceae (syn. Lythraceae) possessing $2 \mathrm{n}=16$ or 18 number of chromosomes (Madhuri, 2017), is an emerging fruit crop of tropical and subtropical regions (Kumar et al., 2020). In India, pomegranate is being grown in an area of 2.62 lakh hectares with an annual production of 30.34 lakh tonnes and a productivity of 11.58 tonnes/ha (Anonymous, 2019). The pomegranate produces three types of flowers on the same plant, viz., male flowers (bell shaped), hermaphrodite flowers (vase shaped) and intermediate flowers (tubular shaped) (Prasad et al., 2012). If the fruit set occurs in intermediate flowers, the fruits drop off before reaching maturity, even if some fruits reach maturity, they become mis-shaped (Aravind et al., 2018). The ovary of male flower is rudimentary, while the ovary of intermediate flower is degenerating, where as the ovary of the hermaphrodite flowers is well formed with a large base. Male flowers drop and do not set fruit, so hermaphrodite flowers are the only ones to produce fruit (Yahya et al., 2017). A positive relation was found between the percentage of hermaphrodite flowers and

Corresponding author: Dr. S. Firoz Hussain
Assistant Professor, Dr. YSR Horticultural University, College of
Horticulture, Anantharajupeta-516 105, Andhra Pradesh, India
E-mail: fkhanshaik@gmail.com
Tel.: +91-9963889398

Copyright (c) 2021 Ukaaz Publications. All rights reserved.

Email: ukaaz@yahoo.com; Website: www.ukaazpublications.com bearing capacity (Chaudhari and Desai, 1993). In India, the pomegranate exhibits three distinct seasons of flowering, i.e., Ambe bahar (January - February), Mrig bahar (June - July) and Hastha bahar (September - October) (Kumar et al., 2008). The availability of irrigation water, the occurrence and extent of disease and pest damage, and consumer demand, all influence the choice of a particular season or bahar at a given location (Hoda and Hoda, 2013).

In temperate and subtropical climatic conditions of India, pomegranate grows as a deciduous shrub, but in tropical climate, the plant prefers to remain evergreen and flowers almost throughout the year. As a result of this, the yield becomes low and the fruits will be of varying sizes (Aziz et al., 2012). Regulation of flowering in pomegranate in tropical climatic conditions to obtain higher proportions of hermaphrodite flowers is an ideal option for obtaining higher yields and economic returns (Aseri et al., 2008). This can be achieved by withholding irrigation (moisture stress), use of defoliants (ethrel), plant bioregulators and root exposure for about 60 days in advance of normal flowering. These are the major horticultural interventions that influence flowering and improve fruit yield in pomegranate (Kumar et al., 2020).

Plant growth regulators or chemicals are said to influence physiological processes and endogenous hormone levels in horticultural crops, resulting in quantitative and qualitative improvements (Phawa et al., 2017). Plant growth regulators or 
chemicals such as methyl jasmonate (MeJA), nitrobenzene (NB), and paclobutrazol (PBZ) at various concentrations influence flowering, fruit set, fruit retention, and yield in a variety of fruit crops (Bhujbal et al., 2013) and are especially useful in pomegranate cultivation (Chaudhari and Desai, 1993).

Pomegranate is propagated through air layering, hard wood cuttings, grafting and tissue culture. Among these, tissue culture is the most popular method of developing commercial orchards. The flowering behaviour of tissue culture or grafted plants has not been studied properly. Furthermore, despite its high commercial importance, the production protocols for inducing better flowering for large scale commercial pomegranate cultivation has received little attention.

Therefore, the present investigation was carried out to elucidate the effects of different chemicals, viz., methyl jasmonate, nitrobenzene and paclobutrazol to induce flowering during desired period in such a way that the plant produces higher number of hermaphrodite flowers with improved fruit set which ultimately leads to improvement of fruit yield in different plant propagules of pomegranate such as tissue culture plants, grafted plants or air layer plants, during two seasons, i.e., ambe bahar (January February) and hastha bahar (September - October) in this research. We chose 'Bhagwa', a common commercial pomegranate cultivar, for the study. The fruits are large sweet with attractive red skin, deep red arils, soft seeds (mellowness) which enhanced its commercial value for a distant market (Dhinesh et al., 2017).

\section{Materials and Methods}

The present investigation was conducted at Research Farm of ICAR - Indian Institute of Horticultural Research, Hesaraghatta, Bengaluru during two seasons, i.e., ambe bahar (January - February), 2016 and hastha bahar (September-October), 2016-17. There were two factors, i.e., first factor included propagules $(\mathrm{P})$ with three levels $\left(\mathrm{P}_{1}\right.$ - Tissue culture plants, $\mathrm{P}_{2}$ - Grafted plants and $\mathrm{P}_{3}$-Air layer plants and second factor included chemical applications $(C)$ with ten levels $\left(C_{1}\right.$ - methyl jasmonate (MeJA) $100 \mathrm{ppm}_{\text {plant }}{ }^{-1}, \mathrm{C}_{2}$ - MeJA $150 \mathrm{ppm}$ plant $^{-1}, \mathrm{C}_{3}$ - MeJA 200 ppm plant ${ }^{-1}, C_{4}$ - nitrobenzene (NB) $1.0 \mathrm{ml} \mathrm{litre}^{-1}$ plant $^{-1}$, $\mathrm{C}_{5}$ - NB $1.5 \mathrm{ml} \mathrm{litre}{ }^{-1}$ plant $^{-1}, \mathrm{C}_{6}$ - NB $2.0 \mathrm{ml} \mathrm{litre}^{-1}$ plant $^{-1}, \mathrm{C}_{7}$ - soil drenching of paclobutrazol (PBZ) $0.375 \mathrm{~g}$ a.i. $\mathrm{m}^{-1}$ canopy diameter 30 days after bahar treatment, $\mathrm{C}_{8}$ - soil drenching of PBZ $0.375 \mathrm{~g}$ a.i. $\mathrm{m}^{-1}$ canopy diameter 45 days after bahar treatment, $\mathrm{C}_{9}$-soil drenching of PBZ $0.375 \mathrm{~g}$ a.i. $\mathrm{m}^{-1}$ canopy diameter 60 days after bahar treatment and $\mathrm{C}_{10}$ - Control (without chemicals). All the plants were initially subjected to stress by with holding irrigation for a month and defoliation was achieved by foliar application of ethrel $2 \mathrm{ml} /$ litre (prior to imposition of treatments), followed by twig pruning. The experiment was laid out in factorial randomized block design with three replications. The experiment was conducted on four years old healthy and uniform different propagules of pomegranate cv. Bhagwa planted at $5.0 \mathrm{~m} \times 4.5 \mathrm{~m}$ spacing under drip irrigation system. The recommended dose of fertilizers was applied and uniform intercultural operations were carried out to raise the crop. The mean monthly weather data during experimentation period are presented in Table 1. Data were recorded on number of male, intermediate and hermaphrodite flowers, percentage of fruit set (\%), number of fruits per plant, fruit yield (kg per plant), fruit weight $(\mathrm{g})$, fruit length $(\mathrm{cm})$, fruit width $(\mathrm{cm})$ and fruit volume $(\mathrm{ml})$ and the data was analyzed statistically as per the methods suggested by Gomez and Gomez (1984).

Table 1: Mean monthly weather condition prevailed during experimentation period 2016-17

\begin{tabular}{|c|c|c|c|c|c|c|c|}
\hline \multirow[t]{2}{*}{ Month } & \multirow[t]{2}{*}{ Year } & \multicolumn{2}{|c|}{ Temperature $\left({ }^{\circ} \mathrm{C}\right)$} & \multirow{2}{*}{$\begin{array}{c}\text { Mean } \\
\text { Temperature }\left({ }^{\circ} \mathrm{C}\right)\end{array}$} & \multicolumn{2}{|c|}{ Relative humidity (\%) } & \multirow{2}{*}{$\begin{array}{l}\text { Rainfall } \\
(\mathrm{mm})\end{array}$} \\
\hline & & Maximum & Minimum & & Maximum & Minimum & \\
\hline January & 2016 & 27.25 & 15.56 & 21.40 & 81.88 & 46.31 & 0.00 \\
\hline February & 2016 & 33.07 & 19.57 & 26.32 & 74.64 & 51.50 & 0.00 \\
\hline March & 2016 & 36.56 & 22.94 & 29.75 & 66.38 & 41.88 & 0.00 \\
\hline April & 2016 & 37.87 & 23.67 & 30.77 & 69.93 & 43.27 & 0.00 \\
\hline May & 2016 & 34.56 & 21.38 & 55.94 & 75.25 & 38.63 & 81.00 \\
\hline June & 2016 & 29.20 & 19.47 & 24.33 & 82.80 & 44.00 & 68.90 \\
\hline July & 2016 & 29.25 & 20.69 & 24.97 & 79.06 & 48.75 & 170.40 \\
\hline August & 2016 & 27.06 & 20.69 & 23.87 & 80.63 & 58.19 & 16.50 \\
\hline September & 2016 & 25.27 & 21.73 & 23.50 & 80.53 & 54.53 & 14.00 \\
\hline October & 2016 & 26.13 & 18.94 & 22.53 & 59.06 & 37.75 & 0.00 \\
\hline November & 2016 & 26.73 & 18.13 & 22.43 & 63.60 & 28.00 & 0.00 \\
\hline December & 2016 & 28.56 & 16.88 & 22.72 & 72.63 & 36.94 & 0.00 \\
\hline January & 2017 & 28.56 & 16.31 & 22.43 & 73.88 & 38.19 & 0.00 \\
\hline February & 2017 & 28.69 & 15.08 & 21.88 & 54.62 & 18.31 & 0.00 \\
\hline March & 2017 & 32.19 & 17.56 & 24.87 & 56.75 & 22.63 & 0.00 \\
\hline April & 2017 & 29.67 & 20.47 & 25.07 & 70.87 & 32.60 & 12.10 \\
\hline May & 2017 & 26.25 & 20.81 & 23.53 & 79.56 & 53.00 & 176.40 \\
\hline June & 2017 & 27.27 & 20.60 & 23.93 & 79.40 & 65.80 & 49.65 \\
\hline
\end{tabular}




\section{Results}

\subsection{Number of male flowers}

During ambe bahar, it was conspicuous from Table 2 that lowest number of male flowers (215.8) was observed in grafted plants $\left(\mathrm{P}_{2}\right)$ which was significantly different from rest of the propagules, i.e., tissue culture $\left(\mathrm{P}_{1}\right)$ and air layer plants $\left(\mathrm{P}_{3}\right)$. Among the chemicals, soil drenching of paclobutrazol $0.375 \mathrm{~g}$ a.i. $\mathrm{m}^{-1}$ canopy diameter 60 days after bahar treatment $\left(\mathrm{C}_{9}\right)$ resulted in least male flower production (222.4). The interaction effect of the chemicals across the propagules showed significant differences for male flower production. The grafted plants $\left(\mathrm{P}_{2}\right)$ produced less number of male flowers (162.0) when foliar sprayed with nitrobenzene $2.0 \mathrm{ml} \mathrm{litre}^{-1}$ plant $^{-1}\left(\mathrm{C}_{6}\right)$. In case of hastha bahar, lowest number of male flowers (202.4) were apparent in grafted plants $\left(\mathrm{P}_{2}\right)$ which differed significantly from rest of the propagules, i.e., tissue culture $\left(\mathrm{P}_{1}\right)$ and air layer plants $\left(\mathrm{P}_{3}\right)$. Among the chemicals, soil drenching of paclobutrazol $0.375 \mathrm{~g}$ a.i. $\mathrm{m}^{-1}$ canopy diameter 30 days after bahar treatment $\left(\mathrm{C}_{7}\right)$ resulted in least male flower production (204.8). The interaction effects of the chemicals across the propagules exhibited significant variations for male flower production. Soil drenching of paclobutrazol $0.375 \mathrm{~g}$ a.i. $\mathrm{m}^{-1}$ canopy diameter 30 days after bahar treatment $\left(\mathrm{C}_{7}\right)$ to grafted plants $\left(\mathrm{P}_{2}\right)$ registered less number of male flowers plant ${ }^{-1}(184.3)$.

\subsection{Number of intermediate flowers}

During ambe bahar, the data presented in Table 2 elucidated that tissue culture plants $\left(\mathrm{P}_{1}\right)$ recorded higher number of intermediate flowers (274.7) which altered significantly from the other propagules like grafted and air layer plants. With respect to the effect of chemicals applied, soil drenching of paclobutrazol $0.375 \mathrm{~g}$ a.i. $\mathrm{m}^{-1}$ canopy diameter 30 days after bahar treatment $\left(\mathrm{C}_{7}\right)$ registered highest number of intermediate flowers (232.7). The interaction effect of the chemicals across the propagules indicated that significant differences were apparent for intermediate flower production. Foliar application of methyl jasmonate $200 \mathrm{ppm} \mathrm{litre}^{-1}$ plant $^{-1}\left(\mathrm{C}_{3}\right)$ to tissue culture plants $\left(\mathrm{P}_{1}\right)$ led to high intermediate flower production (314.7). In hastha bahar, tissue culture plants $\left(\mathrm{P}_{1}\right)$ produced higher number of intermediate flowers (218.9) which differed significantly from the other propagules. Among the chemicals, application of nitrobenzene $1.0 \mathrm{ml}$ litre $^{-1}$ plant $^{-1}\left(\mathrm{C}_{4}\right)$ registered highest number of intermediate flowers (228.0). The interaction effect of the chemicals across the propagules indicated significant differences for intermediate flower production. It is evident that tissue culture plants $\left(\mathrm{P}_{1}\right)$ produced highest number of intermediate flowers (246.7) when applied with nitrobenzene $1.0 \mathrm{ml} \mathrm{litre} \mathrm{e}^{-1}$ plant $^{-1}$ as foliar spray $\left(\mathrm{C}_{4}\right)$.

\subsection{Number of hermaphrodite flowers}

During ambe bahar, highest number of hermaphrodite flowers (261.6) was apparent in tissue culture plants $\left(P_{1}\right)$ which was significantly different from rest of the propagules. Among the chemicals, soil drenching of paclobutrazol $0.375 \mathrm{~g}$ a.i. $\mathrm{m}^{-1}$ canopy diameter 60 days after bahar treatment $\left(\mathrm{C}_{9}\right)$ resulted in highest hermaphrodite flower production (267.3) which was significantly different from other chemicals. The interaction effect of the chemicals across the propagules showed significant differences for hermaphrodite flower production. The tissue culture plants $\left(\mathrm{P}_{1}\right)$ produced significantly high number of hermaphrodite flowers (335.3) when soil drenched with paclobutrazol $0.375 \mathrm{~g}^{\text {a.i. }} \mathrm{m}^{-1}$ canopy diameter 60 days after bahar treatment $\left(\mathrm{C}_{9}\right)$. During hastha bahar, highest number of hermaphrodite flowers (233.2) was produced by tissue culture plants $\left(\mathrm{P}_{1}\right)$ which differed significantly from rest of the propagules. Among the chemicals, application of nitrobenzene as foliar spray $2.0 \mathrm{ml} \mathrm{litre}^{-1}$ plant $^{-1}\left(\mathrm{C}_{6}\right)$ implicated in registering high number of hermaphrodite flowers plant ${ }^{-1}$ (253.8) which varied significantly from the rest of the chemicals used. With respect to the effect of chemicals across the propagules, application of nitrobenzene $2.0 \mathrm{ml}$ litre $^{-1}$ plant $^{-1}\left(\mathrm{C}_{6}\right)$ to tissue culture plants $\left(\mathrm{P}_{1}\right)$ resulted in production of higher number of hermaphrodite flowers (275.2) which was on par with soil drenching of paclobutrazol $0.375 \mathrm{~g}$ a.i. $\mathrm{m}^{-1}$ canopy diameter 60 days after bahar treatment $\left(C_{9}\right)(269.8)$. (Table 2).

\subsection{Percentage of fruit set (\%)}

During ambe bahar, the data presented in Table 3 indicated that tissue culture plants $\left(\mathrm{P}_{1}\right)$ recorded highest fruit set percentage (63.41 $\%$ ) which was altered significantly from other propagules like grafted $\left(\mathrm{P}_{2}\right)$ and air layer plants $\left(\mathrm{P}_{3}\right)$. Among the chemicals, soil drenching of paclobutrazol $0.375 \mathrm{~g}$ a.i. $\mathrm{m}^{-1}$ canopy diameter 60 days after bahar treatment $\left(\mathrm{C}_{9}\right)$ implicated in enhancing fruit set percentage $(65.67$ $\%)$. Significant variations were apparent with respect to interaction of chemicals across the propagules to percentage of fruit set. In tissue culture plants $\left(\mathrm{P}_{1}\right)$, high fruit set percentage $(70.36 \%)$ was observed when soil drenched with paclobutrazol $0.375 \mathrm{~g}$ a.i. $\mathrm{m}^{-1}$ canopy diameter 60 days after bahar treatment $\left(\mathrm{C}_{9}\right)$. In case of hastha bahar, the data presented in Table 3 demonstrated that air layer plants $\left(\mathrm{P}_{3}\right)$ recorded highest fruit set percentage $(48.60 \%)$ which varied significantly from other propagules like grafted $\left(\mathrm{P}_{2}\right)$ and tissue culture plants $\left(\mathrm{P}_{1}\right)$. Among the chemicals, application of nitrobenzene $2.0 \mathrm{ml}$ litre $^{-1}$ plant $^{-1}$ as foliar spray $\left(\mathrm{C}_{6}\right)$ registered highest fruit set percentage $(50.86 \%)$. Significant variations were apparent with respect to interaction of chemicals across the propagules to percentage of fruit set. In air layer plants $\left(\mathrm{P}_{3}\right)$, foliar application of nitrobenzene $2.0 \mathrm{ml}$ litre $^{-1}$ plant $^{-1}\left(\mathrm{C}_{6}\right)$ implicated in enhancing percentage of fruit set $(53.30 \%)$.

During ambe bahar, tissue culture plants $\left(\mathrm{P}_{1}\right)$ registered highest fruit set percentage due to soil drenching of paclobutrazol and in hastha bahar, foliar spray of nitrobenzene $2.0 \mathrm{ml}$ litre $^{-1}$ plant $^{-1}$ enhanced fruit set percentage in both air layer $\left(\mathrm{P}_{3}\right)$ and tissue culture plants $\left(\mathrm{P}_{1}\right)$. Based on the above results, it can be recommended for planting of either tissue culture or air layer plants.

\subsection{Number of fruits per plant}

In case of ambe bahar, the data presented in Table 3 exonerated that the tissue culture plants $\left(\mathrm{P}_{1}\right)$ produced significantly higher number of fruits plant ${ }^{-1}$ (169.13). Across the chemicals, foliar spray of nitrobenzene $2.0 \mathrm{ml} \mathrm{litre}^{-1}$ plant $^{-1}\left(\mathrm{C}_{6}\right)$ produced highest number of fruits (159.11). The effect of chemicals across the propagules varied significantly for fruit number plant ${ }^{-1}$. The tissue culture plants $\left(\mathrm{P}_{1}\right)$ exhibited highest number of fruits plant ${ }^{-1}$ (199.66) due to soil drenching of paclobutrazol $0.375 \mathrm{~g}$ a.i. $\mathrm{m}^{-1}$ canopy diameter 60 days 
after bahar treatment $\left(\mathrm{C}_{9}\right)$. During hastha bahar, the data presented in Table 3 illustrated that the tissue culture plants $\left(\mathrm{P}_{1}\right)$ produced significantly higher number of fruits plant ${ }^{-1}(108.10)$ as compared to other propagules. Across the chemicals, foliar spray of nitrobenzene $2.0 \mathrm{ml} \mathrm{litre}^{-1}$ plant $^{-1}\left(\mathrm{C}_{6}\right)$ produced highest number of fruits (128.61). The effect of chemicals across the propagules varied significantly for number of fruits plant ${ }^{-1}$. The tissue culture plants $\left(\mathrm{P}_{1}\right)$ exhibited highest fruit number plant ${ }^{-1}$ (136.81) due to application of nitrobenzene $2.0 \mathrm{ml} \mathrm{litre}^{-1}$ plant $^{-1}$ as foliar spray $\left(\mathrm{C}_{6}\right)$.

\subsection{Fruit yield (kg / plant)}

In case of ambe bahar, the data in Table 3 showed significant differences with respect to fruit yield plant ${ }^{-1}(\mathrm{~kg})$ across the propagules, and high fruit yield plant $\mathrm{t}^{-1}\left(32.88 \mathrm{~kg} \mathrm{plant}^{-1}\right)$ was produced by tissue culture plants $\left(\mathrm{P}_{1}\right)$ which varied significantly from the rest of the propagules. Across the chemicals, soil drenching of paclobutrazol $0.375 \mathrm{~g}$ a.i. $\mathrm{m}^{-1}$ canopy diameter 60 days after bahar treatment $\left(\mathrm{C}_{9}\right)$ registered high fruit yield $\left(30.54 \mathrm{~kg}\right.$ plant $\left.{ }^{-1}\right)$. From the table, it was noted that significant alterations were evident with chemicals across the propagules. The tissue culture plants $\left(\mathrm{P}_{1}\right)$ recorded fruit yield of $41.20 \mathrm{~kg}$ plant $^{-1}$ due to soil drenching of paclobutrazol $0.375 \mathrm{~g}$ a.i. $\mathrm{m}^{-1}$ canopy diameter 60 days after bahar treatment $\left(\mathrm{C}_{9}\right)$. During hastha bahar, the data presented in Table 3 revealed that significant differences were not evident with respect to fruit yield plant ${ }^{-1}(\mathrm{~kg})$ among the propagules. Nevertheless, the tissue culture plants $\left(\mathrm{P}_{1}\right)$ registered highest fruit yield $\left(35.57 \mathrm{~kg}\right.$ plant $\left.{ }^{-1}\right)$. Among the chemicals, application of nitrobenzene $2.0 \mathrm{ml} \mathrm{litre}^{-1}$ plant $^{-1}$ $\left(\mathrm{C}_{6}\right)$ implicated in enhancing fruit yield $\left(48.19 \mathrm{~kg} \mathrm{plant}^{-1}\right)$ which varied significantly from the other applied chemicals. It was further observed that significant differences were evident pertaining to influence of chemicals across the propagules. Application of nitrobenzene $2.0 \mathrm{ml}$ litre $^{-1}$ plant $^{-1}$ as foliar spray $\left(\mathrm{C}_{6}\right)$ to grafted plants $\left(\mathrm{P}_{2}\right)$ produced highest yield $\left(51.44 \mathrm{~kg} \mathrm{plant}^{-1}\right)$.

\subsection{Fruit weight (g)}

During ambe bahar, the data presented in Table 4 suggested that highest fruit weight $(192.7 \mathrm{~g})$ was observed in tissue culture plants $\left(\mathrm{P}_{1}\right)$. Significant variations were evident across the chemicals and highest fruit weight (198.1 g) was registered with soil drenching of paclobutrazol $0.375 \mathrm{~g}$ a.i. $\mathrm{m}^{-1}$ canopy diameter 60 days after bahar treatment $\left(\mathrm{C}_{9}\right)$. The response of the propagules to the chemicals differed significantly for fruit weight and the tissue culture plants $\left(\mathrm{P}_{1}\right)$ produced fruits with highest fruit weight $(206.70 \mathrm{~g})$ when soil drenched with paclobutrazol $0.375 \mathrm{~g}$ a.i. $\mathrm{m}^{-1}$ canopy diameter 60 days after bahar treatment $\left(\mathrm{C}_{9}\right)$. The data presented in Table 4 for hastha bahar indicated that fruit weight $(363.44 \mathrm{~g})$ was high in grafted plants $\left(\mathrm{P}_{2}\right)$ which altered significantly from the rest of the propagules. Significant variations were evident across the chemicals and highest fruit weight $(375.92 \mathrm{~g}$ ) was recorded due to foliar spray of nitrobenzene $2.0 \mathrm{ml}$ litre $^{-1}$ plant $^{-1}\left(\mathrm{C}_{6}\right)$. The response of the propagules to the effect of different chemicals differed significantly for fruit weight and the grafted plants $\left(\mathrm{P}_{2}\right)$ registered highest fruit weight $(424.72 \mathrm{~g})$ owing to foliar spray of nitrobenzene $2.0 \mathrm{ml}$ litre $^{-1}$ plant $^{-1}\left(\mathrm{C}_{6}\right)$.

\subsection{Fruit length $(\mathrm{cm})$}

During ambe bahar, the data in Table 4 depicted that the tissue culture plants $\left(\mathrm{P}_{1}\right)$ produced fruits with highest length $(6.54 \mathrm{~cm})$. Across the chemicals, application of nitrobenzene $2.0 \mathrm{ml} \mathrm{litre}^{-1}$ plant $^{-1}$ as foliar spray $\left(\mathrm{C}_{6}\right)$ implicated in incrementing fruit length $(6.55 \mathrm{~cm})$. Despite significant variations were not evident with respect to the effect of chemicals across the propagules for fruit length; highest fruit length $(6.69 \mathrm{~cm})$ was observed in tissue culture plants $\left(\mathrm{P}_{1}\right)$ with soil drenching of paclobutrazol $0.375 \mathrm{~g}$ a.i. $\mathrm{m}^{-1}$ canopy diameter 30 days after bahar treatment $\left(\mathrm{C}_{7}\right)$. In case of hastha bahar, the data depicted in Table 4 implied that the tissue culture plants $\left(\mathrm{P}_{1}\right)$ produced fruits of highest length $(8.08 \mathrm{~cm})$. Pertaining to the effect of chemicals, application of nitrobenzene $2.0 \mathrm{ml}$ litre $^{-1}$ plant $^{-1}$ as foliar spray $\left(\mathrm{C}_{6}\right)$ implicated in increasing fruit length $(8.76 \mathrm{~cm})$. Regarding the influence of chemicals across the propagules, the grafted plants $\left(\mathrm{P}_{2}\right)$ produced fruits having highest fruit length $(9.00 \mathrm{~cm})$ when applied with nitrobenzene $2.0 \mathrm{ml}$ litre $^{-1}$ plant $^{-1}$ as foliar spray $\left(\mathrm{C}_{6}\right)$.

\subsection{Fruit width $(\mathrm{cm})$}

In case of ambe bahar, the tissue culture plants $\left(\mathrm{P}_{1}\right)$ produced fruits of highest width $(6.80 \mathrm{~cm})$. Across the chemicals, soil drenching of paclobutrazol $0.375 \mathrm{~g}$ a.i. $\mathrm{m}^{-1}$ canopy diameter 30 days after bahar treatment $\left(\mathrm{C}_{7}\right)$ registered highest fruit width $(6.77 \mathrm{~cm})$. There were no significant differences with respect to effect of chemicals across the propagules for fruit width. However, soil drenching of paclobutrazol $0.375 \mathrm{~g}$ a.i. $\mathrm{m}^{-1}$ canopy diameter 30 days after bahar treatment $\left(\mathrm{C}_{7}\right)$ to tissue culture plants $\left(\mathrm{P}_{1}\right)$ recorded highest fruit width $(7.06 \mathrm{~cm})$. During hastha bahar, the data presented in Table 4 revealed that significant variations were apparent with regard to fruit width across the propagules and the grafted plants $\left(\mathrm{P}_{2}\right)$ produced fruits of highest width $(8.10 \mathrm{~cm})$. Regarding the effect of chemicals, foliar spray of nitrobenzene $2.0 \mathrm{ml}$ litre $^{-1}$ plant $^{-1}\left(\mathrm{C}_{6}\right)$ implicated in enhancing fruit width $(8.71 \mathrm{~cm})$. Pertaining to the influence of chemicals across the propagules, grafted plants $\left(\mathrm{P}_{2}\right)$ when foliar sprayed with nitrobenzene $2.0 \mathrm{ml}$ litre $^{-1}$ plant $^{-1}\left(\mathrm{C}_{6}\right)$ produced fruits of highest width $(8.90 \mathrm{~cm})$.

\subsection{Fruit volume (ml)}

In case of ambe bahar, the data presented in Table 4 indicated that the fruit volume $(167.55 \mathrm{ml})$ was recorded high in fruits produced from tissue culture plants $\left(\mathrm{P}_{1}\right)$. Across the chemicals, it was noticed that soil drenching of paclobutrazol $0.375 \mathrm{~g}$ a.i. $\mathrm{m}^{-1}$ canopy diameter 45 days after bahar treatment $\left(\mathrm{C}_{8}\right)$ implicated in incrementing fruit volume $(170.46 \mathrm{ml})$. Significant differences were apparent with respect to effect of chemicals across the propagules for fruit volume. Soil drenching of paclobutrazol $0.375 \mathrm{~g}$ a.i. $\mathrm{m}^{-1}$ canopy diameter 60 days after bahar treatment $\left(\mathrm{C}_{9}\right)$ to tissue culture plants $\left(\mathrm{P}_{1}\right)$ registered highest fruit volume $(183.83 \mathrm{ml})$. During hastha bahar, the data presented in Table 4 demonstrated that highest volume $(325.61 \mathrm{ml})$ was recorded in fruits produced from grafted plants $\left(\mathrm{P}_{2}\right)$. Pertaining to the influence of chemicals, it was observed that application of nitrobenzene $2.0 \mathrm{ml}$ litre $^{-1}$ plant $^{-1}$ as foliar spray $\left(\mathrm{C}_{6}\right)$ associated with enhancing fruit volume $(345.13 \mathrm{ml})$. Significant differences were apparent with respect to effect of chemicals across the propagules for fruit volume. The fruits with highest volume $(387.20 \mathrm{ml})$ were obtained from grafted plants $\left(\mathrm{P}_{2}\right)$ when sprayed with nitrobenzene $2.0 \mathrm{ml}$ litre $^{-1}$ plant $^{-1}\left(\mathrm{C}_{6}\right)$. 
Table 2: Effect of different propagules, chemicals and their interactions on flower induction in pomegranate

\begin{tabular}{|c|c|c|c|c|c|c|}
\hline \multirow[t]{2}{*}{ Treatments } & \multicolumn{2}{|c|}{ Number of male flowers } & \multicolumn{2}{|c|}{ Number of intermediate flowers } & \multicolumn{2}{|c|}{ Number of hermaphrodite flowers } \\
\hline & $\begin{array}{c}\text { Ambe bahar } \\
\text { (January - } \\
\text { February) } \\
2016\end{array}$ & $\begin{array}{c}\text { Hastha bahar } \\
\text { (September - } \\
\text { October) } \\
2016-17\end{array}$ & $\begin{array}{c}\text { Ambe bahar } \\
\text { (January - } \\
\text { February) } \\
2016\end{array}$ & $\begin{array}{c}\text { Hastha bahar } \\
\text { (September - } \\
\text { October) } \\
2016-17\end{array}$ & $\begin{array}{c}\text { Ambe bahar } \\
\text { (January - } \\
\text { February) } \\
2016\end{array}$ & $\begin{array}{l}\text { Hastha bahar } \\
\text { (September- } \\
\text { October) } \\
2016-17\end{array}$ \\
\hline & \multicolumn{2}{|c|}{ Propagules } & \multicolumn{2}{|c|}{ Propagules } & \multicolumn{2}{|c|}{ Propagules } \\
\hline$P_{1}$ & 318.53 & 224.53 & 274.73 & 218.88 & 261.60 & 233.16 \\
\hline $\mathbf{P}_{2}$ & 215.86 & 202.40 & 172.06 & 211.43 & 190.66 & 212.70 \\
\hline $\mathbf{P}_{3}$ & 257.26 & 213.91 & 172.26 & 207.86 & 195.93 & 220.12 \\
\hline $\operatorname{SEm}( \pm)$ & 3.88 & 2.33 & 3.66 & 1.64 & 2.83 & 1.22 \\
\hline \multirow[t]{2}{*}{ C.D. $(5 \%)$} & 11.02 & 6.63 & 10.39 & 4.66 & 8.04 & 3.48 \\
\hline & \multicolumn{2}{|c|}{ Chemical applications (C) } & \multicolumn{2}{|c|}{ Chemical applications (C) } & \multicolumn{2}{|c|}{ Chemical applications (C) } \\
\hline $\mathrm{C}_{1}$ & 311.10 & 207.58 & 201.55 & 218.29 & 180.00 & 198.93 \\
\hline $\mathrm{C}_{2}$ & 245.99 & 206.72 & 222.44 & 220.61 & 216.00 & 205.77 \\
\hline $\mathrm{C}_{3}$ & 280.44 & 207.75 & 226.22 & 210.9 & 192.88 & 202.35 \\
\hline $\mathrm{C}_{4}$ & 271.99 & 206.39 & 180.44 & 228.96 & 216.66 & 228.94 \\
\hline $\mathrm{C}_{5}$ & 251.22 & 215.20 & 201.11 & 224.7 & 229.55 & 241.54 \\
\hline $\mathrm{C}_{6}$ & 246.22 & 217.78 & 193.77 & 217.97 & 237.77 & 253.77 \\
\hline $\mathrm{C}_{7}$ & 249.77 & 204.84 & 232.66 & 203.57 & 216.88 & 229.44 \\
\hline $\mathrm{C}_{8}$ & 235.77 & 212.33 & 213.77 & 212.12 & 232.66 & 235.13 \\
\hline $\mathrm{C}_{9}$ & 222.44 & 206.55 & 219.77 & 211.87 & 267.33 & 243.65 \\
\hline $\mathrm{C}_{10}$ (Control) & 323.33 & 250.99 & 171.77 & 178.23 & 170.88 & 180.39 \\
\hline SEm $( \pm)$ & 7.09 & 4.27 & 11.57 & 5.19 & 8.96 & 3.88 \\
\hline \multirow[t]{2}{*}{ C.D. $(5 \%)$} & 20.13 & 12.11 & 32.86 & 14.75 & 25.45 & 11.02 \\
\hline & \multicolumn{2}{|c|}{$\begin{array}{l}\text { Propagules } \times \text { Chemical } \\
\text { applications }(C)\end{array}$} & \multicolumn{2}{|c|}{$\begin{array}{c}\text { Propagules } \times \text { Chemical } \\
\text { applications }(C)\end{array}$} & \multicolumn{2}{|c|}{$\begin{array}{l}\text { Propagules } \times \text { Chemical } \\
\text { applications }(C)\end{array}$} \\
\hline $\mathbf{P}_{1 \times} \mathbf{C}_{1}$ & 364.66 & 218.04 & 275.33 & 227.58 & 226.66 & 204.58 \\
\hline$P_{1 \times} C_{2}$ & 334.66 & 199.45 & 268.00 & 236.82 & 230.00 & 206.84 \\
\hline$P_{1 \times} C_{3}$ & 330.66 & 203.93 & 314.66 & 228.64 & 231.33 & 198.3 \\
\hline$P_{1 \times} C_{4}$ & 320.66 & 207.93 & 244.00 & 246.66 & 248.66 & 236.1 \\
\hline$P_{1 \times} C_{5}$ & 309.66 & 226.44 & 292.00 & 246.47 & 268.66 & 253.93 \\
\hline$P_{1 \times} C_{6}$ & 306.00 & 244.06 & 246.66 & 226.48 & 274.00 & 275.22 \\
\hline $\mathbf{P}_{1 \times} \mathbf{C}_{7}$ & 286.00 & 214.51 & 290.00 & 185.56 & 282.00 & 245.05 \\
\hline $\mathbf{P}_{1 \times} \mathbf{C}_{8}$ & 282.66 & 231.34 & 301.33 & 198.10 & 296.00 & 258.95 \\
\hline$P_{1 \times} C_{9}$ & 281.33 & 223.78 & 310.00 & 216.80 & 335.33 & 269.82 \\
\hline$P_{1 \times} C_{10}$ & 369.33 & 275.84 & 205.33 & 175.68 & 223.33 & 182.77 \\
\hline $\mathbf{P}_{2 \times} \mathrm{C}_{1}$ & 259.33 & 186.40 & 163.33 & 210.34 & 154.66 & 185.14 \\
\hline $\mathbf{P}_{2 \times} \mathbf{C}_{2}$ & 226.66 & 202.65 & 196.00 & 222.16 & 176.00 & 200.75 \\
\hline $\mathbf{P}_{2 \times} \mathbf{C}_{3}$ & 214.66 & 212.33 & 175.33 & 192.53 & 182.66 & 192.91 \\
\hline $\mathbf{P}_{2 \times} \mathbf{C}_{4}$ & 214.66 & 203.07 & 142.00 & 211.14 & 212.66 & 226.25 \\
\hline$P_{2 \times} C_{5}$ & 168.00 & 202.66 & 152.00 & 205.75 & 223.33 & 238.36 \\
\hline$P_{2 \times} C_{6}$ & 162.00 & 212.17 & 164.66 & 216.83 & 240.00 & 246.00 \\
\hline $\mathbf{P}_{2 \times} \mathbf{C}_{7}$ & 236.66 & 184.36 & 211.33 & 213.03 & 166.66 & 214.64 \\
\hline
\end{tabular}




\begin{tabular}{|c|c|c|c|c|c|c|}
\hline$P_{2 \times} C_{8}$ & 213.33 & 205.74 & 168.00 & 226.33 & 196.66 & 224.46 \\
\hline$P_{2 \times} C_{9}$ & 190.00 & 200.01 & 181.33 & 227.56 & 208.66 & 233.33 \\
\hline$P_{2 x} C_{10}$ & 273.33 & 214.66 & 166.66 & 188.63 & 145.33 & 165.18 \\
\hline$P_{3 \times} C_{1}$ & 309.33 & 218.29 & 166.00 & 216.94 & 158.66 & 207.07 \\
\hline$P_{3 \times} C_{2}$ & 176.66 & 218.07 & 203.33 & 202.84 & 242.00 & 209.73 \\
\hline $\mathbf{P}_{3 \times} \mathrm{C}_{3}$ & 296.00 & 207.00 & 188.66 & 211.54 & 164.66 & 215.86 \\
\hline$P_{3 \times} C_{4}$ & 280.66 & 208.18 & 155.33 & 229.07 & 188.66 & 224.47 \\
\hline $\mathbf{P}_{3 \times} \mathrm{C}_{5}$ & 276.00 & 216.52 & 159.33 & 221.9 & 196.66 & 232.33 \\
\hline$P_{3 \times} C_{6}$ & 270.66 & 197.11 & 170.00 & 210.61 & 199.33 & 240.09 \\
\hline $\mathbf{P}_{3 \times} \mathbf{C}_{7}$ & 226.66 & 215.64 & 196.66 & 212.12 & 202.00 & 228.63 \\
\hline$P_{3 \times} C_{8}$ & 211.33 & 199.93 & 172.00 & 211.93 & 205.33 & 221.99 \\
\hline$P_{3 \times} C_{9}$ & 196.00 & 195.87 & 168.00 & 191.25 & 258.00 & 227.8 \\
\hline $\mathbf{P}_{3 \times} C_{10}$ & 327.33 & 262.47 & 143.33 & 170.39 & 144.00 & 193.22 \\
\hline $\operatorname{SEm}( \pm)$ & 12.28 & 7.39 & 11.57 & 5.19 & 8.96 & 3.88 \\
\hline C.D. $(5 \%)$ & 34.86 & 20.99 & 32.86 & 14.75 & 25.45 & 11.02 \\
\hline
\end{tabular}

$\mathrm{P}_{1}$ - Tissue culture plants, $\mathrm{P}_{2}$ - Grafted plants, $\mathrm{P}_{3}$ - Air layer plants, $\mathrm{C}_{1}$ - Methyl Jasmonate (MeJA) $100 \mathrm{ppm}$ plant ${ }^{-1}, \mathrm{C}_{2}-\mathrm{MeJA}_{150} \mathrm{ppm}$ plant ${ }^{-1}$, $\mathrm{C}_{3}$-MeJA 200 ppm plant ${ }^{-1}, \mathrm{C}_{4}$ - Nitrobenzene (NB) $1.0 \mathrm{ml} \mathrm{litre}^{-1}$ plant $^{-1}, \mathrm{C}_{5}-\mathrm{NB} 1.5 \mathrm{ml} \mathrm{litre}{ }^{-1}$ plant $^{-1}, \mathrm{C}_{6}-\mathrm{NB} 2.0 \mathrm{ml} \mathrm{litre}^{-1}$ plant $^{-1}, \mathrm{C}_{7}$-soil drenching of paclobutrazol (PBZ) $0.375 \mathrm{~g}$ a.i. $\mathrm{m}^{-1}$ canopy diameter 30 days after bahar treatment, $\mathrm{C}_{8}$ - soil drenching of PBZ $0.375 \mathrm{~g}$ a.i. $\mathrm{m}^{-1}$ canopy diameter 45 days after bahar treatment, $\mathrm{C}_{9}$ - soil drenching of PBZ $0.375 \mathrm{~g}$ a.i. $\mathrm{m}^{-1}$ canopy diameter 60 days after bahar treatment, $\mathrm{C}_{10}{ }^{-} \mathrm{Control}^{\text {(without }}$ chemical treatment).

Table 3: Effect of different propagules, chemicals and their interactions on yield and its attributes in pomegranate

\begin{tabular}{|c|c|c|c|c|c|c|}
\hline \multirow[t]{2}{*}{ Treatments } & \multicolumn{2}{|c|}{ Percentage of fruit set $(\%)$} & \multicolumn{2}{|c|}{ Number of fruits per plant } & \multicolumn{2}{|c|}{ Fruit yield (kg / plant) } \\
\hline & $\begin{array}{c}\text { Ambe bahar } \\
\text { (January - } \\
\text { February) } \\
2016\end{array}$ & $\begin{array}{c}\text { Hastha bahar } \\
\text { (September - } \\
\text { October) } \\
2016-17\end{array}$ & $\begin{array}{c}\text { Ambe bahar } \\
\text { (January - } \\
\text { February) } \\
2016\end{array}$ & $\begin{array}{c}\text { Hastha bahar } \\
\text { (September - } \\
\text { October) } \\
2016-17\end{array}$ & $\begin{array}{c}\text { Ambe bahar } \\
\text { (January - } \\
\text { February) } \\
2016\end{array}$ & $\begin{array}{c}\text { Hastha bahar } \\
\text { (September- } \\
\text { October) } \\
2016-17\end{array}$ \\
\hline & \multicolumn{2}{|c|}{ Propagules } & \multicolumn{2}{|c|}{ Propagules } & \multicolumn{2}{|c|}{ Propagules } \\
\hline$P_{1}$ & 63.41 & 46.40 & 169.13 & 108.10 & 32.88 & 35.57 \\
\hline $\mathbf{P}_{2}$ & 56.50 & 45.38 & 103.03 & 95.90 & 19.44 & 35.21 \\
\hline $\mathbf{P}_{3}$ & 57.58 & 48.60 & 143.70 & 107.24 & 24.70 & 34.14 \\
\hline SEm ( \pm$)$ & 0.72 & 0.54 & 1.80 & 1.11 & 0.68 & 0.42 \\
\hline \multirow[t]{2}{*}{ CD (5\%) } & 2.06 & 1.55 & 5.13 & 3.15 & 1.94 & N.S. \\
\hline & \multicolumn{2}{|c|}{ Chemical applications (C) } & \multicolumn{2}{|c|}{ Chemical applications (C) } & \multicolumn{2}{|c|}{ Chemical applications (C) } \\
\hline $\mathrm{C}_{1}$ & 52.58 & 48.19 & 119.11 & 95.88 & 20.13 & 28.72 \\
\hline $\mathrm{C}_{2}$ & 59.41 & 48.20 & 122.88 & 98.96 & 24.54 & 30.75 \\
\hline $\mathrm{C}_{3}$ & 57.20 & 42.52 & 129.55 & 85.80 & 22.84 & 26.47 \\
\hline $\mathrm{C}_{4}$ & 58.95 & 47.55 & 138.66 & 108.56 & 25.75 & 39.17 \\
\hline $\mathrm{C}_{5}$ & 60.51 & 48.49 & 145.66 & 117.02 & 27.34 & 43.10 \\
\hline $\mathrm{C}_{6}$ & 62.53 & 50.86 & 159.11 & 128.61 & 30.20 & 48.19 \\
\hline $\mathrm{C}_{7}$ & 60.49 & 44.31 & 149.55 & 101.51 & 28.03 & 35.71 \\
\hline $\mathrm{C}_{8}$ & 63.53 & 45.91 & 154.00 & 107.73 & 29.31 & 36.78 \\
\hline $\mathrm{C}_{9}$ & 65.67 & 44.14 & 156.66 & 107.81 & 30.54 & 36.82 \\
\hline $\mathrm{C}_{10}$ (Control) & 50.76 & 47.74 & 111.00 & 85.60 & 18.03 & 24.04 \\
\hline
\end{tabular}




\begin{tabular}{|c|c|c|c|c|c|c|}
\hline $\operatorname{SEm}( \pm)$ & 1.32 & 1.00 & 3.30 & 2.02 & 1.25 & 0.78 \\
\hline \multirow[t]{2}{*}{ C.D. $(5 \%)$} & 3.77 & 2.84 & 9.36 & 5.75 & 3.55 & 2.22 \\
\hline & \multicolumn{2}{|c|}{$\begin{array}{l}\text { Propagules } \times \text { Chemical } \\
\text { applications }(C)\end{array}$} & \multicolumn{2}{|c|}{$\begin{array}{c}\text { Propagules } \times \text { Chemical } \\
\text { applications }(C)\end{array}$} & \multicolumn{2}{|c|}{$\begin{array}{l}\text { Propagules } \times \text { Chemical } \\
\text { applications }(\mathrm{C})\end{array}$} \\
\hline$P_{1 \times} C_{1}$ & 58.29 & 46.63 & 145.33 & 95.15 & 25.95 & 28.27 \\
\hline$P_{1 \times} C_{2}$ & 59.06 & 49.62 & 146.66 & 102.37 & 27.18 & 31.01 \\
\hline$P_{1 \times} C_{3}$ & 60.32 & 45.80 & 154.66 & 90.62 & 29.13 & 27.6 \\
\hline$P_{1 \times} C_{4}$ & 63.58 & 43.07 & 169.00 & 101.57 & 33.16 & 36.05 \\
\hline$P_{1 \times} C_{5}$ & 64.21 & 47.94 & 170.66 & 121.73 & 33.83 & 43.95 \\
\hline$P_{1 \times} C_{6}$ & 66.33 & 49.76 & 181.00 & 136.81 & 35.95 & 49.42 \\
\hline$P_{1 \times} C_{7}$ & 67.00 & 42.87 & 195.66 & 105.05 & 39.20 & 36.36 \\
\hline$P_{1 \times} C_{8}$ & 68.01 & 44.98 & 198.33 & 116.41 & 40.46 & 38.98 \\
\hline$P_{1 \times} C_{9}$ & 70.36 & 46.88 & 199.66 & 126.32 & 41.20 & 40.49 \\
\hline$P_{1 \times} C_{10}$ & 57.01 & 46.47 & 130.33 & 85.02 & 22.78 & 23.58 \\
\hline$P_{2 \times} C_{1}$ & 48.44 & 40.71 & 92.00 & 86.17 & 16.54 & 26.92 \\
\hline$P_{2 \times} C_{2}$ & 53.42 & 46.64 & 93.66 & 96.69 & 17.01 & 32.52 \\
\hline$P_{2 \times} C_{3}$ & 57.59 & 42.12 & 97.00 & 81.2 & 17.75 & 26.33 \\
\hline$P_{2 \times} C_{4}$ & 60.10 & 48.27 & 108.00 & 105.35 & 21.3 & 40.76 \\
\hline$P_{2 \times} C_{5}$ & 62.91 & 49.53 & 125.66 & 109.98 & 24.73 & 43.79 \\
\hline$P_{2 \times} C_{6}$ & 64.42 & 52.85 & 143.33 & 121.14 & 28.61 & 51.44 \\
\hline $\mathbf{P}_{2 \times} \mathbf{C}_{7}$ & 52.08 & 46.23 & 89.33 & 92.77 & 16.81 & 34.93 \\
\hline$P_{2 \times} C_{8}$ & 59.54 & 46.57 & 95.00 & 91.31 & 18.17 & 34.11 \\
\hline$P_{2 \times} C_{9}$ & 59.68 & 43.41 & 97.66 & 87.44 & 18.87 & 35.70 \\
\hline$P_{2 x} C_{10}$ & 46.79 & 37.47 & 88.66 & 86.98 & 14.62 & 25.63 \\
\hline$P_{3 \times} C_{1}$ & 51.01 & 51.39 & 120.00 & 106.32 & 17.92 & 31.0 \\
\hline$P_{3 \times} C_{2}$ & 65.76 & 46.72 & 128.33 & 97.82 & 29.45 & 28.7 \\
\hline$P_{3 \times} C_{3}$ & 53.70 & 39.64 & 137.00 & 85.58 & 21.65 & 25.5 \\
\hline$P_{3 \times} C_{4}$ & 53.17 & 52.95 & 139.00 & 118.75 & 22.80 & 40.7 \\
\hline $\mathbf{P}_{3 \times} C_{5}$ & 54.41 & 51.31 & 140.66 & 119.35 & 23.48 & 41.6 \\
\hline$P_{3 \times} C_{6}$ & 56.84 & 53.30 & 153.00 & 127.88 & 26.05 & 43.7 \\
\hline$P_{3 \times} C_{7}$ & 62.40 & 46.66 & 163.66 & 106.71 & 28.07 & 35.8 \\
\hline$P_{3 \times} C_{8}$ & 63.05 & 52.04 & 168.66 & 115.49 & 29.30 & 37.3 \\
\hline$P_{3 \times} C_{9}$ & 66.98 & 48.08 & 172.66 & 109.66 & 31.55 & 34.3 \\
\hline$P_{3 x} C_{10}$ & 48.50 & 43.89 & 114.00 & 84.82 & 16.69 & 22.9 \\
\hline SEm ( \pm$)$ & 2.30 & 1.73 & 5.71 & 3.51 & 2.17 & 1.35 \\
\hline CD $(5 \%)$ & 6.53 & 4.92 & 16.22 & 9.96 & 6.16 & 3.84 \\
\hline
\end{tabular}

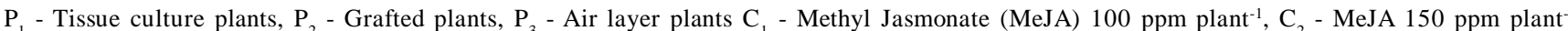

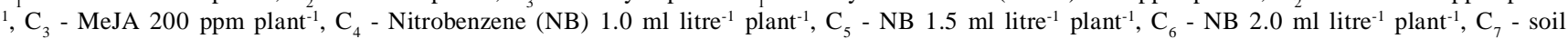
drenching of paclobutrazol (PBZ) $0.375 \mathrm{~g}$ a.i. $\mathrm{m}^{-1}$ canopy diameter 30 days after bahar treatment, $\mathrm{C}_{8}$ - soil drenching of PBZ $0.375 \mathrm{~g}^{2} . \mathrm{i} . \mathrm{m}^{-1}$ canopy diameter 45 days after bahar treatment, $\mathrm{C}_{9}$ - soil drenching of PBZ $0.375 \mathrm{~g}$ a.i. $\mathrm{m}^{-1}$ canopy diameter 60 days after bahar treatment, $\mathrm{C}_{10}$ - Control (without chemical treatment). 
Table 4: Effect of different propagules, chemicals and their interactions on fruiting parameters in pomegranate

\begin{tabular}{|c|c|c|c|c|c|c|c|c|}
\hline \multirow[t]{2}{*}{ Treatments } & \multicolumn{2}{|c|}{ Fruit weight (g) } & \multicolumn{2}{|c|}{ Fruit length $(\mathrm{cm})$} & \multicolumn{2}{|c|}{ Fruit width $(\mathrm{cm})$} & \multicolumn{2}{|c|}{ Fruit volume $(\mathrm{ml})$} \\
\hline & $\begin{array}{c}\text { Ambe } \\
\text { bahar } \\
\text { (January - } \\
\text { February) } \\
2016\end{array}$ & $\begin{array}{c}\text { Hastha } \\
\text { bahar } \\
\text { (September }- \\
\text { October) } \\
2016-17\end{array}$ & $\begin{array}{c}\text { Ambe } \\
\text { bahar } \\
\text { (January - } \\
\text { February) } \\
2016\end{array}$ & $\begin{array}{c}\text { Hastha } \\
\text { bahar } \\
\text { (September- } \\
\text { October) } \\
2016-17\end{array}$ & $\begin{array}{c}\text { Ambe } \\
\text { bahar } \\
\text { (January- } \\
\text { February) } \\
2016\end{array}$ & $\begin{array}{c}\text { Hastha } \\
\text { bahar } \\
\text { (September- } \\
\text { October) } \\
2016-17\end{array}$ & $\begin{array}{c}\text { Ambe } \\
\text { bahar } \\
\text { (January- } \\
\text { February) } \\
2016\end{array}$ & $\begin{array}{c}\text { Hastha } \\
\text { bahar } \\
\text { (September- } \\
\text { October) } \\
2016-17\end{array}$ \\
\hline & \multicolumn{2}{|c|}{ Propagules } & \multicolumn{2}{|c|}{ Propagules } & \multicolumn{2}{|c|}{ Propagules } & \multicolumn{2}{|c|}{ Propagules } \\
\hline $\mathbf{P}_{1}$ & 192.70 & 326.15 & 6.54 & 8.08 & 6.80 & 8.00 & 167.55 & 299.99 \\
\hline $\mathbf{P}_{2}$ & 189.94 & 363.44 & 6.38 & 7.99 & 6.65 & 8.10 & 165.26 & 325.61 \\
\hline $\mathbf{P}_{3}$ & 171.85 & 315.72 & 6.08 & 7.83 & 6.34 & 7.82 & 135.54 & 278.34 \\
\hline $\operatorname{SEm}( \pm)$ & 1.19 & 1.86 & 0.04 & 0.04 & 0.04 & 0.04 & 1.94 & 2.91 \\
\hline \multirow[t]{2}{*}{ C.D. $(5 \%)$} & 3.39 & 5.28 & 0.12 & 0.12 & 0.13 & 0.12 & 5.52 & 8.27 \\
\hline & \multicolumn{2}{|c|}{$\begin{array}{c}\text { Chemical } \\
\text { applications (C) }\end{array}$} & \multicolumn{2}{|c|}{$\begin{array}{c}\text { Chemical } \\
\text { applications (C) }\end{array}$} & \multicolumn{2}{|c|}{$\begin{array}{c}\text { Chemical } \\
\text { applications (C) }\end{array}$} & \multicolumn{2}{|c|}{$\begin{array}{c}\text { Chemical } \\
\text { applications (C) }\end{array}$} \\
\hline $\mathrm{C}_{1}$ & 170.63 & 300.35 & 6.43 & 7.80 & 6.62 & 7.64 & 154.94 & 267.33 \\
\hline $\mathrm{C}_{2}$ & 173.85 & 310.97 & 6.25 & 7.76 & 6.49 & 7.76 & 148.38 & 287.26 \\
\hline $\mathrm{C}_{3}$ & 178.40 & 308.79 & 6.35 & 7.86 & 6.60 & 7.87 & 160.47 & 284.01 \\
\hline $\mathrm{C}_{4}$ & 186.46 & 361.50 & 6.42 & 8.20 & 6.66 & 8.08 & 156.24 & 325.1 \\
\hline $\mathrm{C}_{5}$ & 194.68 & 369.02 & 6.35 & 8.54 & 6.64 & 8.2 & 149.46 & 336.22 \\
\hline $\mathrm{C}_{6}$ & 195.92 & 375.92 & 6.55 & 8.76 & 6.67 & 8.71 & 161.75 & 345.13 \\
\hline $\mathbf{C}_{7}$ & 193.72 & 352.66 & 6.44 & 7.78 & 6.77 & 8.02 & 159.48 & 315.07 \\
\hline $\mathrm{C}_{8}$ & 195.92 & 343.68 & 6.27 & 7.85 & 6.59 & 8.03 & 170.46 & 306.18 \\
\hline $\mathrm{C}_{9}$ & 198.13 & 347.33 & 6.33 & 7.71 & 6.69 & 7.93 & 166.20 & 322.81 \\
\hline $\mathrm{C}_{10}($ Control $)$ & 160.57 & 280.83 & 5.96 & 7.40 & 6.24 & 7.48 & 133.76 & 224.03 \\
\hline SEm ( $( \pm)$ & 2.18 & 3.39 & 0.08 & 0.07 & 0.08 & 0.08 & 3.55 & 5.32 \\
\hline \multirow[t]{2}{*}{ C.D. $(5 \%)$} & 6.19 & 9.64 & 0.22 & 0.22 & 0.24 & 0.23 & 10.07 & 15.09 \\
\hline & \multicolumn{2}{|c|}{$\begin{array}{c}\text { Propagules } \times \text { Chemical } \\
\text { applications }(C)\end{array}$} & \multicolumn{2}{|c|}{$\begin{array}{l}\text { Propagules } \times \text { Chemical } \\
\text { applications }(\mathrm{C})\end{array}$} & \multicolumn{2}{|c|}{$\begin{array}{c}\text { Propagules } \times \text { Chemical } \\
\text { applications }(\mathrm{C})\end{array}$} & \multicolumn{2}{|c|}{$\begin{array}{l}\text { Propagules } \times \text { Chemical } \\
\text { applications }(\mathrm{C}) \\
\end{array}$} \\
\hline $\mathrm{P}_{1 \times} \mathrm{C}_{1}$ & 178.53 & 297.44 & 6.56 & 8.13 & 6.68 & 7.80 & 163.80 & 273.90 \\
\hline$P_{1 \times} C_{2}$ & 185.56 & 303.05 & 6.62 & 8.16 & 6.85 & 7.83 & 170.46 & 277.33 \\
\hline$P_{1 \times} C_{3}$ & 188.33 & 304.61 & 6.65 & 7.93 & 6.93 & 7.70 & 180.43 & 290.63 \\
\hline$P_{1 \times} C_{4}$ & 196.30 & 354.80 & 6.52 & 8.16 & 6.66 & 8.20 & 147.36 & 324.00 \\
\hline$P_{1 \times} C_{5}$ & 198.27 & 361.01 & 6.46 & 8.53 & 6.74 & 8.40 & 154.03 & 343.93 \\
\hline$P_{1 \times} C_{6}$ & 198.93 & 361.42 & 6.62 & 8.83 & 6.72 & 8.63 & 177.26 & 344.03 \\
\hline$P_{1 \times} C_{7}$ & 200.36 & 345.99 & 6.69 & 7.83 & 7.06 & 7.83 & 180.60 & 314.03 \\
\hline$P_{1 \times} C_{8}$ & 204.10 & 334.86 & 6.48 & 7.96 & 6.73 & 8.33 & 173.96 & 307.23 \\
\hline$P_{1 \times} C_{9}$ & 206.70 & 320.43 & 6.64 & 7.73 & 7.03 & 7.93 & 183.83 & 294.13 \\
\hline$P_{1 \times} C_{10}$ & 169.90 & 277.93 & 6.19 & 7.50 & 6.56 & 7.36 & 143.76 & 230.70 \\
\hline $\mathbf{P}_{2 \times} \mathrm{C}_{1}$ & 180.66 & 312.36 & 6.52 & 7.56 & 6.75 & 7.73 & 167.00 & 290.70 \\
\hline$P_{2 \times} C_{2}$ & 182.43 & 336.26 & 6.31 & 7.46 & 6.62 & 7.70 & 157.33 & 313.90 \\
\hline $\mathbf{P}_{2 \times} \mathbf{C}_{3}$ & 184.96 & 323.99 & 6.46 & 7.76 & 6.62 & 8.13 & 173.86 & 304.03 \\
\hline$P_{2 \times} C_{4}$ & 198.83 & 387.05 & 6.56 & 8.70 & 6.90 & 8.33 & 160.73 & 340.60 \\
\hline$P_{2 \times} C_{5}$ & 201.86 & 397.93 & 6.55 & 8.90 & 6.90 & 8.60 & 177.26 & 357.40 \\
\hline
\end{tabular}




\begin{tabular}{|c|c|c|c|c|c|c|c|c|}
\hline$P_{2 \times} C_{6}$ & 204.90 & 424.72 & 6.63 & 9.00 & 6.78 & 8.90 & 164.06 & 387.20 \\
\hline $\mathbf{P}_{2 \times} \mathbf{C}_{7}$ & 191.50 & 376.17 & 6.41 & 7.90 & 6.67 & 8.00 & 150.63 & 323.93 \\
\hline$P_{2 \times} C_{8}$ & 193.43 & 373.63 & 6.30 & 7.96 & 6.62 & 7.76 & 180.43 & 323.96 \\
\hline$P_{2 \times} C_{9}$ & 195.70 & 408.05 & 6.26 & 7.50 & 6.63 & 8.36 & 174.10 & 383.66 \\
\hline$P_{2 x} C_{10}$ & 165.10 & 294.26 & 5.84 & 7.16 & 6.03 & 7.50 & 147.23 & 230.73 \\
\hline $\mathbf{P}_{3 \times} \mathbf{C}_{1}$ & 152.70 & 291.24 & 6.22 & 7.70 & 6.44 & 7.40 & 134.03 & 237.40 \\
\hline $\mathbf{P}_{3 \times} \mathbf{C}_{2}$ & 153.56 & 293.60 & 5.83 & 7.66 & 6.01 & 7.76 & 117.36 & 270.56 \\
\hline$P_{3 \times} C_{3}$ & 161.90 & 297.78 & 5.93 & 7.90 & 6.24 & 7.80 & 127.13 & 257.36 \\
\hline$P_{3 \times} C_{4}$ & 164.26 & 342.65 & 6.19 & 7.73 & 6.41 & 7.73 & 160.63 & 310.70 \\
\hline $\mathbf{P}_{3 \times} \mathbf{C}_{5}$ & 183.93 & 348.11 & 6.05 & 8.20 & 6.28 & 7.60 & 117.10 & 307.33 \\
\hline$P_{3 \times} C_{6}$ & 183.93 & 341.62 & 6.39 & 8.46 & 6.52 & 8.60 & 143.93 & 304.16 \\
\hline$P_{3 \times} C_{7}$ & 189.30 & 335.82 & 6.22 & 7.63 & 6.56 & 8.23 & 147.23 & 307.26 \\
\hline$P_{3 \times} C_{8}$ & 190.23 & 322.55 & 6.05 & 7.63 & 6.41 & 8.00 & 157.00 & 287.36 \\
\hline$P_{3 \times} C_{9}$ & 192.00 & 313.52 & 6.09 & 7.90 & 6.41 & 7.50 & 140.66 & 290.63 \\
\hline$P_{3 x} C_{10}$ & 146.73 & 270.29 & 5.84 & 7.53 & 6.13 & 7.60 & 110.30 & 210.66 \\
\hline $\operatorname{SEm}( \pm)$ & 3.78 & 5.88 & 0.14 & 0.13 & 0.14 & 0.14 & 6.15 & 9.21 \\
\hline C.D. $(5 \%)$ & 10.73 & 16.71 & N.S. & 0.38 & N.S. & 0.40 & 17.45 & 26.15 \\
\hline
\end{tabular}

$P_{1}$ - Tissue culture plants, $P_{2}$ - Grafted plants, $P_{3}$ - Air layer plants $C_{1}$ - Methyl Jasmonate (MeJA) 100 ppm plant $^{-1}, C_{2}-$ MeJA 150 ppm plant ${ }^{1}, \mathrm{C}_{3}$ - MeJA 200 ppm plant ${ }^{-1}, \mathrm{C}_{4}$ - Nitrobenzene (NB) $1.0 \mathrm{ml} \mathrm{litre}^{-1}$ plant $^{-1}, \mathrm{C}_{5}-\mathrm{NB} 1.5 \mathrm{ml} \mathrm{litre}^{-1} \mathrm{plant}^{-1}, \mathrm{C}_{6}-\mathrm{NB} 2.0 \mathrm{ml} \mathrm{litre}^{-1} \mathrm{plant}^{-1}, \mathrm{C}_{7}-\mathrm{soil}$ drenching of paclobutrazol (PBZ) $0.375 \mathrm{~g}$ a.i. $\mathrm{m}^{-1}$ canopy diameter 30 days after bahar treatment, $\mathrm{C}_{8}$ - soil drenching of PBZ $0.375 \mathrm{~g}^{2} . \mathrm{i}^{-1} \mathrm{~m}^{-1}$ canopy diameter 45 days after bahar treatment, $\mathrm{C}_{9}$ - soil drenching of PBZ $0.375 \mathrm{~g}$ a.i. $\mathrm{m}^{-1}$ canopy diameter 60 days after bahar treatment, $\mathrm{C}_{10}$ Control (without chemical treatment).

\section{Discussion}

Pomegranate fruit is in high demand because of its wide range of medicinal properties and nutritional value, as well as its high antioxidant ability (Ali et al., 2014). This crop is evergreen and flowers throughout the year in the tropical climatic conditions of India. As a result of the depletion of plant reserves caused by nonsynchronized flowering, the yield becomes lower and the fruit quality will be poor (Ram et al., 2010). Since the pomegranate has a good commercial demand, it is critical to improve the number of hermaphrodite flowers, yield and its attributes in order to obtain good market returns, and ongoing efforts are made in this direction. Crop synchronization, also known as flower regulation, is an excellent way to encourage abundant harvesting (Madhuri, 2017). In many perennial fruit crops, plant growth regulators/chemicals play an important role in regulating flowering and fruiting. These plant growth regulators increase production by improving the internal physiology of developing fruits, which improves fruit set and corrects various physiological disorders, resulting in improved quality and yield (Chaudhari and Desai, 1993; Bhujbal et al., 2013). We investigated the effects of three plant growth regulators, methyl jasmonate (MeJA), nitrobenzene (NB), and paclobutrazol (PBZ), at various concentrations on different propagules (tissue culture plants, grafted plants and air layer plants) on various parameters such as flowering pattern, fruit set, yield and its attributes.

\subsection{Induction of flowering}

The grafted plants $\left(\mathrm{P}_{2}\right)$ showed production of less number of male flowers during ambe bahar and hastha bahar due to soil drenching of paclobutrazol which could possibly be due to production of more number of hermaphrodite flowers and suppression of apical dominance and the activation of the axillary meristems during the floral cycle. Flowering in pomegranate is characterized as having both hermaphrodite and functionally male flowers on the same tree, a condition referred to as andromonoecy (Wetzstein et al., 2011). Male flowers may contribute as a source of pollen. However, they drop and fail to set fruits. In fruit crops (pomegranate and mango), male flower production has lesser consequence and they drop off as soon as pollination is completed. At the same time, development of male flowers do not exert strong force on sink as their production is similar to vegetative growth development.

During both the seasons, tissue culture plants produced higher number of intermediate flowers plant ${ }^{-1}$, following application of chemicals like paclobutrazol, methyl jasmonate and nitrobenzene. In fruit crops, gibberellins are destined for vegetative growth, whereas cytokinin induces reproductive phase (Alabadi et al., 2009). Increase in intermediate flower production in paclobutrazol treated plants might be ascribed to elevated levels of cytokinins which may have helped in flower bud differentiation and subsequently leading to flowering. However, the ovary of intermediate flowers is degenerative type. If fruit set takes place in such flowers, they may drop before reaching maturity, even if some fruits which reach maturity become misshaped (Dhinesh, 2010). The present investigation is in consensus with the findings of Upreti et al. (2013) who propounded that paclobutrazol besides affecting gibberellins also increases cytokinin content in mango leaves to elicit flowering responses.

In both seasons, the tissue culture plants $\left(\mathrm{P}_{1}\right)$ produced high number of hermaphrodite flowers plant ${ }^{-1}$ owing to paclobutrazol application 
through soil drenching apart from foliar spray of nitrobenzene. Floral induction is considered to be the result of elevated levels of up-regulated florigenic promoter (FP) and down-regulated vegetative promoter (VP), primarily gibberellins (Nartvarant et al., 2000; Davenport, 2007). Paclobutrazol, a gibberellin inhibitor, reduces VP level and thereby increases FP/VP ratio which stimulates flowering in the shoots of fruit crops (Voon et al., 1991; Yeshitela et al., 2004; Adil et al., 2011; Iglesius et al., 2007). The increase in the number of hermaphrodite flowers due to paclobutrazol application could be ascribed to its suppression of gibberellin production by inhibiting the oxidation of ent - kaurene to ent - kaurenoic acid in the gibberellin biosynthetic pathway. The reduction of gibberellin level reduces cell division and elongation and, as a direct morphological consequence, vegetative growth is restricted (Dalziel and Lawrence, 1984). The promotion in flowering may be attributed either to the increased synthesis of the floral stimulus in an inductive cycle or by affecting the balance between the flower - inhibiting and flower - promoting hormones. According to Kurian and Iyer (1992), paclobutrazol can enhance the total phenolic content of terminal buds and alter the phloem to xylem ratio of the stem, which is important in restricting the vegetative growth and enhancing flowering by altering assimilate partitioning and patterns of nutrient supply for new growth in mango. The results enumerated as above are in consonance with the current investigation. It is evident that exposure of plants to stress in pomegranate promoted accumulation of proline which acted as an endogenous signal to induce flowering (Neale et al., 1990). Further, a positive correlation was observed between leaf proline content and the number of hermaphrodite flowers produced (Powerwanto and Inoue, 1990). Application of ethrel ( $2 \mathrm{ml} /$ litre) to defoliate pomegranate also regulates flowering (Saroj et al., 2017). Foliar application of ethrel causes activated gene expression of cell-wall degrading enzymes such as cellulase and polygalacturonase. Ethrel perception was found involved in the arrest of stamen development through induction of DNA damage which promotes hermaphrodite flower production in some plant species (Xie et al., 2015). This explanation is supported by the current experiment's findings.

Nitrobenzene is a plant energizer and flowering stimulant. It tilts the auxin, gibberellins, cytokinin, and ethylene ratio favourably and increase the flower forming substances thereby, increasing yield by more than 40 to $50 \%$ (Kavita et al., 2009). As the two chemicals (paclobutrazol and nitrobenzene) are on par with respect to production of hermaphrodite flowers, nitrobenzene would be recommended for induction of flowering in pomegranate owing to its low price and less harmful effects to soil environment compared to paclobutrazol.

\subsection{Fruit yield and its attributes}

Improvement in percentage of fruit set may be due to the reason that paclobutrazol which has been reported to alter source and sink relationship and exert influence on partitioning the photosynthates to the sites of flowering and fruit production with a reduction in vegetative growth. The results obtained in the current investigation are in consonance with those of Swathi et al. (2018) in Jamun cv. Chintamani. The fruit set in pomegranate depends upon hermaphrodite flowers (Chaudhari and Desai, 1993). These results are in line with the present study in pomegranate. Arun (2019) reported that foliar spray of nitrobenzene $3 \mathrm{ml} \mathrm{plant}^{-1}$ enhanced fruit set percentage in Apple cv. Royal Delicious. The role of nitrobenzene in improving fruit set percentage might be due to the fact that it is quickly absorbed into the plants, which has the capacity to increase flowering in plants and maximum number of fruits per plant. Furthermore, it stimulates growth of flower parts and promotes early fruit setting besides it stimulates growth of flower parts and promotes early fruit setting (Mithila et al., 2012).

During ambe bahar and hastha bahar, increase in the number of fruits plant ${ }^{-1}$ was observed in tissue culture plants owing to soil drenching of paclobutrazol and foliar spray of nitrobenzene. This is reflected in the yield data of the present study. In this context, Kurian et al. (2001) reported that paclobutrazol favourably alters the source sink relationship of mango to support the fruit growth with a reduction in vegetative growth. Male flowers drop and generally fail to set, thus fruits develop exclusively from hermaphrodite flowers. A positive relation was found between the percentage of hermaphrodite flowers and bearing capacity (Chaudhari and Desai, 1993). The present investigation is in accordance with above reports.

Soil drenching of paclobutrazol leading to increment in fruit yield in tissue culture plants during ambe bahar might be ascribed to higher percentage of fruit set and number of fruits plant ${ }^{-1}$ in the treated plants. It might also be due to high flowering intensity which resulted in higher fruit number, which ultimately increased fruit yield in paclobutrazol treated plants. Similar results were reported by Anasuya and Selvarajan (2014) in mango cv. Alphonso.

In case of hastha bahar, the grafted plants $\left(\mathrm{P}_{2}\right)$ recorded highest fruit yield owing to foliar spray of nitrobenzene. Increase in fruit yield with application of nitrobenzene in strawberry cv. Festival is reported by Mehraj et al. (2015).

\subsection{Fruiting parameters}

Soil drenching of paclobutrazol to tissue culture plants in ambe bahar produced fruits of highest weight which might possibly be due to lower expenditure of tree reserves to the vegetative growth parameters and consequently no assimilate limitations. It could also be due to better translocation of available assimilates by the developing fruits. Similar trends were in agreement with Sathiyaraj et al. (2014) who claimed that fruit weight in mango cv. Imampasand can be enhanced with soil application of paclobutrazol. Similarly during hastha bahar, grafted plants registered highest fruit weight due to nitrobenzene application. In pomegranate, the grafted plants are characterized by having well developed root system which might have absorbed sufficient nutrients required for fruit growth and development.

In case of two seasons, fruit size in terms of length and width was increased with application of paclobutrazol and nitrobenzene. Such an increase in fruit length and width may be attributed to the fact that paclobutrazol application reduced the vegetative growth (sinks) which in turn, increased the partitioning of nutrients and dry matter towards fruits and thereby enhanced fruit size. As obvious that nitrobenzene possesses auxin like activity, it might have stimulated cell division and cell enlargement and enhance sink strength of the fruit, resulting in faster growth of the fruit and it also may be due to better physiology of developing fruits in terms of better supply of water, nutrients and other compounds vital for their proper growth and development which resulted in improved fruit size. Our findings 
are in conformity with the studies of Wolstenholme et al. (1990) in avocado and Kishor et al. (2016) in pomegranate cv. Bhagwa.

The fruit volume was increased during both the seasons due to application of paclobutrazol and nitrobenzene. This may be due to immediate absorption of auxins, which increased the endogenous auxin level that resulted in cell elongation which accelerated the fruit volume. Similar results are in line with Kishor et al. (2016) who reported that fruit volume in pomegranate cv. Bhagwa was enhanced with NAA application. At the same time, improvement in fruit volume with paclobutrazol could be due to partitioning of assimilates towards the developing fruit. These results are in agreement with Faizan et al. (2000) in litchi.

\section{Conclusion}

From the study it can be concluded that during ambe bahar and hastha bahar the tissue culture plants produced maximum number of hermaphrodite flowers, percentage of fruit set, yield, number of fruits per plant, fruit weight, fruit length, fruit width and volume with soil drenching of paclobutrazol $0.375 \mathrm{~g}$ a.i. $\mathrm{m}^{-1}$ canopy diameter 60 days after bahar treatment and foliar spray of nitrobenzene 2.0 $\mathrm{ml}$ litre $^{-1}$.

\section{Acknowledgements}

The authors are grateful to the ICAR - Indian Institute of Horticultural Research, Hesaraghatta, Bengaluru for providing required facilities to conduct the research.

\section{Conflict of interest}

The authors declare that there are no conflicts of interest relevant to this article.

\section{References}

Adil, O.S.; Rahim, A.; Elamin, O.M. and Bangerth, F.K. (2011). Effects of paclobutrazol (PBZ) on floral induction and aasociated hormonal and metabolic changes of biennially bearing mango (Mangifera indica L.) cultivars during off year. ARPN Journal of Agricultural and Biological Science, 6:55-67.

Alabadi, D.; Blazquez, M.A.; Carbonell, J.; Ferrandiz, C. and Perez Amador, M.A (2009). Instructive roles for hormones in plant development. International Journal of Developmental Biology, 53:597-608.

Ali, AGS.; Ahmad, E.; Zia, ET. and Esmaeil, F. (2014). Paclobutrazol induced biochemical changes in pomegranate (Punica granatum L.) cv. Malas Saveh under freezing stress. International Journal of Horticultural Science and Technology, 1:181-190.

Anasuya, P. and Selvarajan, M. (2014). Effect of dose and time of paclobutrazol application on physiology of flowering and yield in Mango (Mangifera indica L.) cultivar Alphonso. Trends in Biosciences, 7(12):1213-1216.

Aravind, K.; Satya, P. and Jeetendra, K. (2018). Studies on flowering behaviour of pomegranate (Punica granatum L.) with special reference to red aril cultivars. Progressive Agriculture, 18(1):110-112.

Arun, K. (2019). Effect of Nitrobenzene on Flowering, Fruiting and Quality Parameters of Apple cv. Royal Delicious under Cold Dry Temperate Region of Himachal Pradesh. Agricultural Science Digest, pp:1-4.
Aseri, G.K.; Neelam, J.; Jitendra, P.; Rao, A.V.and Meghwal, P.R. (2008). Biofertilizers improve plant growth, fruit yield, nutrition, metabolism and rhizosphere enzyme activities of Pomegranate (Punica granatum L.) in Indian Thar Desert. Scientia Horticulturae, 117:130-135.

Aziz, R.A.B.; Naira, A. and Ashraf, M. (2012). Effect of biostimulants on flowering, fruit drop, yield and return bloom of pomegranate cv. Kandhari Kabuli. The Asian Journal of Horticulture, 7(2):1473477.

Bhujbal, D.S.; Naik, D.M. and Kale, S.A. (2013). Studies on the effect of growth regulators on flowering, fruiting and quality in Sapota. International Journal of Agricultural Sciences, 9:289-92.

Chaudhari, S.M. and Desai, U.T. (1993). Effects of plant growth regulators on flower sex in pomegranate (Punica granatum L.). Indian Journal of Agricultural Science, 63:34-35.

Gomez, K.A. and Gomez, A.A. (1984). Statistical Procedure for Agricultural Research, second ed. John Wiley, New York, pp:278.

Hoda, K. A. and Hoda, A.S.H. (2013). Cracking and fruit quality of pomegranate (Punica granatum L.) as affected by pre harvest sprays of some growth regulators and mineral nutrients. Journal of Horticultural Science and Ornamental Plants, 5(2):71-76.

Dalziel, J. and Lawrence, D.K. (1984). Biochemical and biological effects of kaurene oxidase inhibitors such as paclobutrazol. In R. Menchenett and D.K. Lawrence (eds). Biochemical aspects of synthetic and naturally occurring plant growth regulators. Wantage: British Plant Growth Regulator Group, pp:43-57.

Davenport, T.L. (2007). Reproductive physiology of mango. Brazilian Journal of Plant Physiology, 19:363-376.

Dhinesh, B.K. (2010). Floral Biology of Pomegranate (Punica granatum L.). Fruit, Vegetable and Cereal Science and Biotechnology, pp: 45-50.

Dhinesh, B.K.; Singh, N.V.; Gaikwad, N.; Maity, A.; Suryavanshi, S,K. and Pal, R.K. (2017). Determination of maturity indices for harvesting of pomegranate (Punica granatum). Indian Journal of Agricultural Sciences, 87(9):1225-1330.

Faizan, A.; Mohammad, A. and Ganesh, K. (2000). Effect of paclobutrazol on growth, yield and quality of litchi (Litchi chinensis Sonn.).Indian Journal of Horticulture, 57(4):291-294.

Iglesias, D.J.; Cercos, M.; Olmenero Flores, J,M.; Naranjo, M.A.; Rios G. Carrera E.; Ruiz Rivero, O.; Lliso, I.; Morillon, R.; Tadeo,F.R. and Talon (2007). Physiology of citrus fruiting. Brazilian Journal of Plant Physiology, 19:333-362.

Kavita, A.; Pushpalata, T. and Arti, G. (2009). Impact of Nitrobenzene on physiology and sink capacity of sunflower (Helianthus annus L.). Plant Archives, 9(1):381-383.

Kishor, S.; Maji, S.; Yadav, R.; Meena, K.R. and Kumar, A. (2016). Influence of plant bio regulators and chemicals on yield and fruit quality of young pomegranate (Punica granatum L.) cv. Bhagwa. Environment and Ecology, 34(4):2566-2570.

Kumar, V.; Singh, A.R.; Singh, G.N. and Pal, S.L. (2008). Correlation between flowering and yield characters in pomegranate (Punica granatum L.). Annals of Horticulture, 1(1):73-75.

Kumar, R.; Saroj, P.L.; Sharma, B.D. and Yadav, P.K. (2020). Studies on flowering induction, sex ratio and fruit set improvement in pomegranate. Indian Journal of Horticulture, 77(4):610-618.

Kurian, R.M. and Iyer, C.P.A. (1992). Stem anatomical characters in relation to the vigour in mango. Scientia Horticulturae, 50:245-253. 
Kurian, R.M.; Reddy, Y.T.N.; Sonkar, R.K. and Reddy, V.V.P. (2001). Effect of paclobutrazol on source-sink relationship in mango (Mangifera indica L). Journal of Applied Horticulture, 3:88-90.

Madhuri, S.K. (2017). Recent advances in the production of pomegranate fruit crop. Agriculture Update, 12(4):657-665.

Mithila, D.; Sajal, R. and Imamul, H.S.M. (2012). Effects of nitrobenzene on growth of tomato plants and accumulation of arsenic. Bangladesh Journal of Scientific Research, 25(1):43-52.

Mehraj, H.; Ahsan, M.K.; Hussain, M.S.; Rahman, M.M. and Jamaluddin,A.F.M. (2015). Response of nitrobenzene on growth and yield of strawberry cv. Festival. Bangladesh Research Publication Journal, 10(2):151161.

Nartvaranant, P.; Subhadrabandhu, S. and Tongumpai, P. (2000). Practical aspects in producing off-season mango in Thailand. Acta Horticulture, 509:661-668

Neale, A.D.; Wahleithner, J.A.; Lund, M.; Bonnet, H.T.; Kelly, A.; Meeks, W. D.R.; Peacock, W.J. and Dennis, E.S. (1990). Chitinase (3-1, 3-gluconase, osmotin, and extension are expressed in tobacco explants during flower formation. Plant Cell, 2:673-84

Phawa, T.; Prasad, V.M. and Rajwade, V.B. (2017). Effect of plant growth regulators on growth and flowering of pomegranate (Punica granatum L.) cv. Kandhari in Allahabad agro-climatic conditions. International Journal of Current Microbiology and Applied Sciences, 6:116-121

Powerwanto, R. and Inoue, H. (1990). Effects of air soil temperatures in autumn on flower induction and some physiological responses of Satsuma mandarin. Journal of Japanese Society of Horticultural Sciences, 59:207-14.

Prasad, K.R.S.; Mukunda, G.K.; Mohan Kumar, A.B. and Yathiraj, K. (2012) Comparative studies in certain commercially important varieties of pomegranate (Vegetative growth, flowering, fruit set and yield). The Asian Journal of Horticulture, 7(2):521-523.

Ram, C.; Vilas, T.J. and Jyotsana, S. (2010). Global scenario of pomegranate (Punica granatum L.) culture with special reference to India. Fruit Vegetable Cereal Science and Biotechnology, 4:7-18.
Upreti, K, K.; Reddy, Y.T.N.; Shivu Prasad, S.R.; Bindu, G.V.; Jayaram, H.L. and Shailendra Rajan. (2013). Hormonal changes in response to paclobutrazol induced early flowering in mango cv. Totapuri. Scientia Horticulturae, pp:414-418.

Saroj, P.L.; Sharma, B.D. and Kumar, R. (2017). Pomegranate flower regulation and its physiology. $2^{\text {nd }}$ National Seminar - Cum Farmers Fair. Pomegranate for Health, Growth and Prosperity, pp:87-94.

Sathiyaraj, S.; Velu, G. and Jeya Kumar, P. (2014). Effect of time of application of Paclobutrazol and Potassium Nitrate on Off - Season Flowering and Yield in Mango (Mangifera indica L.) cv. Imampasand. Trends in Biosciences, 7(22):3664-3668.

Swathi, H.; Dinakara, A. J.; Honnabyraiah, M.K., Guruprasad, T.R., Shivanna, M. and Halesh, G.K. (2018). Influence of paclobutrazol on growth and yield of Jamun cv. Chintamani. International Journal of Current Microbiology and Applied Sciences, 7(1):1590-1599.

Voon, C.H.; Pitakpaivan, C.and Tan, S.J. (1991). Mango cropping manipulation with paclobutrazol. Acta Horticulture, 291:218-219.

Xie, S.; Xiaopeng, L.; Xiaoli, Z. and Qun, N. (2015). Effect of water stress on vegetative growth and nitrogen metabolism of pomegranate seedling. Acta Horticulture, 1089:63-69.

Yahya, S.; Zabihollah, Z.; Reza, F. and Ali,R. T. (2017). Effect of deficit irrigation on flowering and fruit properties of pomegranate (Punica granatum cv. Shahvar). Agricultural Water Management, 192: 189-197.

Yeshitela, T.; Robbertse, P.J., and Stassen, P.J.C. (2004). Effects of various inductive periods and chemicals on flowering and vegetative growth of Tommy Atkins and Keitt mango (Mangifera indica) cultivars. New Zealand Journal of Crop and Horticultural Science, 32:209215 .

Wetzstein, H.Y.; Zibin Zhang.; Nadav, R. and Michael W. E. (2011). Characterization of attributes related to fruit size in pomegranate. Hortscience, 46(6):908-912.

Wolstenholme, B.N. (1990). Resource allocation and vegetativereproductive competition: Opportunities for manipulation in evergreen fruit trees. Acta Horticulture, 275:451-460. 